\title{
CORRIGENDUM
}

\section{The semantic network, lexical access, and reading comprehension in monolingual and bilingual children: An individual differences study-CORRIGENDUM}

\author{
TESSA SPÄTGENS \\ University of Amsterdam \\ ROB SCHOONEN \\ Radboud University Nijmegen
}

\section{ADDRESS FOR CORRESPONDENCE}

Tessa Spätgens, University of Amsterdam, Spuistraat 134, 1012 VB Amsterdam, The Netherlands. E-mail: t.m.spatgens@uva.nl

doi: 10.1017/S0142716417000224, published by Cambridge University Press, 18 September 2017

In the article by Spätgens and Schoonen, the penultimate paragraph on page 237 incorrectly states that the coding for the Animacy variable is " $(0$ inanimate, 1 animate)." The correct coding should instead read "(0 animate, 1 inanimate)." We regret this omission and any problems it may have caused.

\section{REFERENCE}

Spätgens, T. \& Schoonen, R. (2017). The semantic network, lexical access, and reading comprehension in monolingual and bilingual children: An individual differences study. Applied Psycholinguistics, 39, 225-256. 